\title{
PROBLEMA GURU DALAM MENGAJARKAN BERHITUNG PEMBAGIAN DIKELAS RENDAH SEKOLAH DASAR
}

\author{
Yantoro \\ Universitas Jambi \\ yantoro@unja.co.id \\ Endang Putri Susanti \\ Universitas Jambi \\ endangputri698@gmail.com \\ Agung Rimba Kurniawan \\ Universitas Jambi \\ agung.rimba@unja.ac.id
}

\begin{abstract}
Abstrak
Penelitian ini bertujuan untuk mendeskripsikan problema guru dalam mengajarakan berhitung pembagian dikelas rendah sekolah dasar. Penelitian ini merupakan penelitian kualitatif dengan jenis penelitian Study Kasus. Subjek penelitian adalah guru wali kelas 2 Sekolah Dasar. Teknik pengumpulan data yang dilakukan yaitu melalui wawancara terstruktur dan dokumentasi.Data yang diperoleh berupa data kualitatif yang berisi deskripsi tentang hasil wawancara dengan guru mengenai strategi pembelajaran berhitung pembagian disekolah dasar. Penelitian ini dilakukan di kelas II SD Negeri 155/1 Sungai Buluh. Hasil penelitian menunjukkan bahwa guru memiliki problema dalam mengajarkan berhitung pembagian dikelas rendah. Berdasarkan indikator berhitung pembagian yaitu pengenalan konsep membagi, pembagian sederhana, dan mengajarkan konsep sisa, problema guru dalam mengajar berhitung pembagian yaitu terdapat pada peserta didik yang masih terfokus pada menghafal perkalian saja tanpa memahami pada proses operasi hitung pembagian itu sendiri.
\end{abstract}

Kata Kunci : Problema Guru, Berhitung Pembagian

\section{Abstract}

This study aims to describe the teacher's problem in teaching arithmetic of elementary school low grade classes. This research is a qualitative research with case study research type. The subject of the research was the teacher in grade 2 of elementary school. Data collection techniques are carried out through structured interviews and documentation. The data obtained in the form of qualitative data that contains a description of the results of interviews with teachers about the learning strategies of elementary school numeracy division. This research was conducted in class II SD

MUBTADI: Jurnal Pendidikan Ibtidaiyah

Vol. 2 No. 1, Juli - Desember 2020

$P$ - ISSN : $2715-7067$

E - ISSN : 2720 - 8850 


\begin{abstract}
Negeri 155/1 Sungai Buluh. The results showed that the teacher had problems in teaching numeracy in the lower classes. Based on the indicators of division counting, namely the introduction of the concept of dividing, simple division, and teaching the rest of the concepts, the problem of the teacher in teaching calculation of division is that there are students who are still focused on memorizing multiplication alone without understanding the process of calculating the distribution itself.

Keywords: Teacher's Problem, Calculating Distribution
\end{abstract}

\title{
PENDAHULUAN
}

Guru memiliki peranan penting didalam proses pembelajaran. Seorang guru harus memberikan bimbingan belajar bagi peserta didik dalam memahami suatu pembelajaran. Pada kegiatan pembelajaran guru juga harus memahami perkembangan peserta didik serta karakteristiknya. Menurut Piaget yang menyatakan bahwa anak usia berkisar antara 7-11 berada pada tahap operasi konkret (Maulana, 2011:70). Pada tahap operasional konkret, kemampuan peserta didik yaitu berfikir secara logis terhadap suatu objek yang bersifat konkret atau nyata dalam kehidupan sehari-hari. Salah satu pembelajaran yang mengaitkan konsep belajar secara abstrak dan bersifat konkret yaitu pembelajaran matematika.

Problema yang biasanya djumpai oleh guru dalam mengajarkan matematika, khususnya pada berhitung pembagian yaitu terdapat pada operasi dalam penyelesain berhitung sendiri. secara umum permasalahan yang sering dilakukan peserta didik dalam menyelesaikan soal pembagian seperti kesalahan perhitungan dan strategi dalam menentukan bilangan dibagi. peserta didik yang mengalami kesulitan belajar akan sulit dalam memahami materi-materi pelajaran yang disampaikan oleh guru, sehingga dapat membuat peserta didik tidak bersemangat dalam belajar. Hal tersebut juga dapat membuat peserta didik menghindari pelajaran. Pada dasarnya kesulitan belajar matematika bukan dari mereka yang tidak mampu dalam belajar, tetapi kondisi tertentu yang membuat mereka tidak sisap dalam belajar.

Matematika merupakan pembelajaran yang mempunyai banyak peranan dalam kehidupan sehari-hari, seperti menghitung, mengukur, menimbang dan lain sebagainya. Pada hakikatnya, matematika merupakan ilmu deduktif, terstruktur tentang pola dan hubungan, bahasa simbol, serta sebagai ratu dan pelayanan ilmu (Rusefendi, 2017). Maka pembelajaran matematika memiliki keteraturan berdasarkan pola yang ditemukan dan menggunakan simbol yang memiliki makna.. Menurut undang-undang Nomor 20 Tahun 2003 Tentang Sistem Nasional pasal 37 Ayat 1 menyatakan bahwa kurikulum pendidikan dasar sampai menengah wajib memuat: pendidikan kewarganegaraan, agama, matematika, IPA, IPS, seni dan budaya, penjas, keterampilan/kejujuran, serta muatan lokal. Berdasarkan undang-undang tersebut bahwa matematika adalah salah satu mata pelajaran wajib yang harus diajarkan sejak jenjang 
pendidikan dasar. Matematika sering dianggap rumit bagi peserta didik. Anggapan tersebut membuat peserta didik kurang memahami dan mempelajari matematika lebih dalam. (Miarti dalam Sundayana, 2015:2) menyatakan "meskipun matematika dianggap memiliki tingkat kesulitan yang tinggi, namun setiap orang harus memahaminya karena merupakan sarana untuk menyelasaikan masalah sehari-hari”. Maka dari itu perlu mempelajari dan memahami pembelajaran matematika agar dapat mengimplementasikannya didalam kehidupan seharihari.

Ciri-ciri mata pelajaran matematika pada umumnya yaitu adanya kegiatan berhitung. Di dalam kegiatan operasi hitung juga terdapat keterampilan yang membantu saat proses pembelajaran. (Maulana 2011: 65) mengungkapkan bahwa keterampilan adalah kemampuan untuk memberi jawaban dengan benar dan tepat. Keterampilan dalam proses pembelajaran matematika dapat diamati ketika peserta didik mampu menghitung dan mengungkapkan jawabannya yang benar dan menggunakan simbol matematika. Keterampilan berhitung merupakan keterampilan dasar yang penting dalam pembelajaran matematika. Keterampilan matematika adalah operasi-operasi dan prosedur-prosedur dalam matematika, yang masingmasing merupakan suatu proses untuk mencari atau memperoleh hasil tertentu (Suwarsono 2008). Keterampilan operasi hitung terdiri dari kegiatan penjumlahan, pengurangan, perkalian, dan pembagian. Salah satu keterampilan operasi hitung yang menjadi pokok materi pembelajaran matematika kelas II saat ini adalah operasi hitung pembagian.

Berdasarkan hasil pengamatan yang dilakukan pada hari Selasa tanggal 12 November 2019 di SD Negeri 155/1 Sungai Buluh, peserta didik melakukan operasi hitung dengan baik, mereka saling membantu jika ada teman lainnya sedikit kesulitan dalam mengerjakan operasi hitung pembagian. Peneliti juga melakukan wawancara kepada wali kelas mengenai hal tersebut. Guru menyatakan bahwa peserta didik cukup pandai dalam berhitung pada operasi hitung pembagian, hanya saja peserta didik juga masih ada yang belum menguasai operasi hitung pembagian dasar.

Guna memperdalam apasaja problema guru dalam mengajarkan berhitung pembagian, maka perlu dilakukan kajian yang mendalam. Sehingga, peneliti tertarik melakukan penelitian dengan judul penelitian "Problema Guru Dalam Mengajarkan Berhitung Pembagian Di Sekolah Dasar".

\section{METODE PENELITIAN}

Penelitian ini merupakan penelitian kualitatif dengan jenis penelitian Studi Kasus. Studi kasus merupakan metode penelitian dalam ilmu sosial, dan dengan melakukan riset atau pemeriksaan mendalam mengenai suatu kejadian. Studi kasus juga dapat digunakan untuk menyelidiki suatu peristiwa, situasi, atau suatu kondisi sosial tertentu dan dapat memberikan wawasan dalam proses yang menjelaskan bagaimana peristiwa situasi tertentu terjadi 
(Hodgetts dalam Unika, 2018:126). Selain itu dalam proses penelitian ini yaitu memperoleh data deskriptif beberntuk tulisan-tulisan yang berasal dari informan.

Subjek penelitian adalah guru wali kelas II Sekolah Dasar. Teknik pengumpulan data yang dilakukan yaitu melalui wawancara terstruktur dan dokumentasi. Data yang diperoleh berupa data kualitatif yang berisi deskripsi tentang hasil wawancara dengan guru mengenai problema guru dalam mengajarkan berhitung pembagian disekolah dasar. Penelitian ini dilakukan di kelas II SD Negeri 155/1 Sungai Buluh.

\section{HASIL PENELITIAN DAN PEMBAHASAN}

Deskripsi lokasi /objek penelitian ini dilakukan di Sekolah Dasar Negeri 155/1 Sungai Buluh, yang terletak di Desa Sungai Buluh, Kecamatan Muara Bulian, Kabupaten Batanghari, Jambi.

Hasil Penelitian

Wawancara dilakukan pada hari selasa 4 Mei 2020 dan 8 Mei 2020 dengan menggunakan teknik wawancara terstrktur, yang berkaitan dengan pembelajaran berhitung pembagian.

Hasil wawancara seebagai berikut.

a. Wawancara dengan guru wali kelas

Peneliti : "Apakah kesulitan yang dialami peserta didik pada pembelajaran berhitung pembagian?"

Subjek : "Kesulitan yang dialami peserta didik adalah ketika peserta didik ragu dalam memahami pembagian berhitung pembagian”.

Peneliti : "Bagaimana solusi ibu dalam menyampaikan konsep pada materi berhitung $? ”$

Subjek : "Solusi dalam menyampaikan konsep pada materi berhitung yaitu dengan diterangkan secara berulang-ulang dengan memberi rumusan, bahwa pembelajaran pembagian itu harus dibantu dengan mengenal rumusan bagi kali kurang”.

Peneliti : "Apa saja yang ibu lakukan untuk membantu kesulitan peserta didik dalam pengenalan konsep membagi ?"

Subjek : “Untuk membantu kesulitan peserta didik dalam pengenalan konsep membagi yaitu bisa menggunakan alat peraga atau media pembelajaran, misalnya dengan buah-buahan atau yang ada disekitar peserta didik”.

Peneliti : "faktor apa yang menyebabkan kesulitan peserta didik dalam berhitung pembagian?"

Subjek : Y Yang menyebabkan kesulitan peserta didik dalam berhitung pembagian yaitu ragu dalam mengerjakan soal. Dalam artian peserta didik tersebut ada 
yang hafal perkalian ada yang tidak, karena jika peserta didik sudah hafal perkalian, maka akan membantu pada proses berhitung pembagian”.

Peneliti : "Strategi pembelajaran apa yang ibu gunakan untuk membantu peserta didik dalam pengenalan konsep membagi ?"

Subjek : " Strategi pembelajaran yang digunakan yaitu dengan mengaitkan konsep pembelajaran baru dengan yang sudah dikenal peserta didik atau juga dengan kerja sama atau kerja kelompok, karena dengan kerja sama akan lebih mudah dalam mengatasi masalah dan didalam kerja kelompok itulah peserta didik bisa saling bantu dalam mengatasi masalah.

Peneliti : "Apakah ibu mengunakan media untuk membantu kesulitan yang dialami peserta didik saat operasi hitung pembagian sederhana?"

Subjek : “ Iya saya menggunakan media komunikatif, contoh media yaitu dengan bantuan berdiskusi”.

Peneliti : "Bagaimana solusi ibu mengajarkan pembagian sederhana pada peserta didik?"

Subjek : "Dari pembagian tersebut diajarkan dengan angka yang terkecil terlebih dahulu, contohnya seperti pembagian dua angka dengan dua angka, dan yang tiga angka dengan tiga angka”.

Peneliti : "Faktor apa yang dapat menyebabkan kesulitan peserta didik dalam pembagian sederhana?”

Subjek : "Sedikit ragu dalam mengerjakan soal berhitung pembagian”.

Peneliti : "Metode apa yang ibu gunakan ketika pembelajaran berhitung pembagian?"

Subjek : "Metode yang digunakan yaitu metode ceramah, metode diskusi, dan metode demonstrasi sesuai dengan kondisi pembelajaran”.

Peneliti : "Strategi pembelajaran apa yang ibu gunakan untuk membantu berhitung pembagian sederhana?"

Subjek : "Strategi yang digunakan yaitu strategi pembelajaran langsug, yaitu yang peserta didik lebih berpusat pada guru dan terkadang juga mengunakan strategi pembelajaran tidak langsung, yaitu adanya interaksi antara peserta didik dengan guru itu sendiri.

Peneliti : "Apakah pembelajaran matematika yang ibu gunakan dapat membantu peserta didik dalam memahami materi konsep sisa pada pembelajarn berhitung pembagian?"

Subjek : "Alhamdulilah peserta didik sedikit sudah memahami materi konsep sisa pada pembelajaran berhitung pembagian”.

Peneliti : "Apa sajakah kendala ibu dalam mengajarkan pembelajaran berhitung pembagian tentang konsep sisa?" 
Subjek : "Kendalanya yaitu ketika peserta didik masih kurang hafal pada perkalian itu sendiri”.

Peneliti : "Bagaimana cara ibu menarik perhatian peserta didik agar mereka lebih optimal dalam memahami materi pada pembelajaran matematika tentang konsep sisa tersebut?"

Subjek : "Untuk menarik perhatian peserta didik agar lebih optimal dalam memahami materi pada pembelajaran matematika tentang konsep sisa tersebut yaitu dengan menggunakan alat peraga atau media pembelajaran dan model pembelajaran yang menarik supaya peserta didik tetap semangat dalam belajar, maka sebelum belajara melakukan peregangan atau belajar sambil bermain.

Peneliti : "Bagaimana upaya yang ibu lakukan untuk membantu peserta didik yang belum bisa memahami konsep sisa tersebut?”

Subjek : " Upaya yang dilakukan yaitu dengan melakukan pendekatan khusus pada anak yang masih bermasalah dalam berhitung pembagian.”

Peneliti : "Strategi pembelajaran apa yang ibu gunakan untuk mengatasi hal tersebut sehingga dapat membantu peserta didik dalam memahami konsep sisa ?"

Subjek : "Strateginya yaitu dengan menggunakan strategi pembelajaran langsung, dimana disini guru menjelaskan terlebih dahulu dengan menggunakan metode ceramah, kemudian baru diterapkan pada peserta didiknya sehingga ada interaksi antara peserta didik dan guru”.

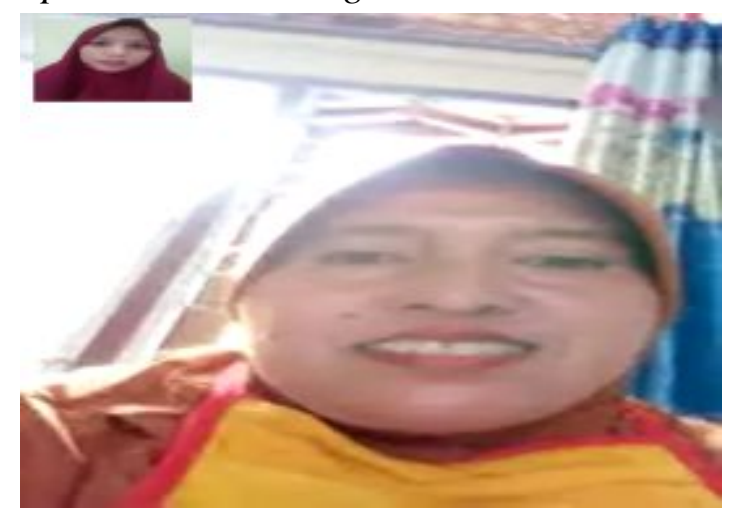

Gambar 4.1 wawancara dengan guru

\section{PEMBAHASAN}

Problema yang biasanya djumpai oleh guru dalam mengajarkan matematika, khususnya pada berhitung pembagian yaitu terdapat pada operasi dalam penyelesain berhitung sendiri. secara umum permasalahan yang sering dilakukan peserta didik dalam menyelesaikan soal pembagian seperti kesalahan perhitungan dan strategi dalam menentukan 
bilangan dibagi. peserta didik yang mengalami kesulitan belajar akan sulit dalam memahami materi-materi pelajaran yang disampaikan oleh guru, sehingga dapat membuat peserta didik tidak bersemangat dalam belajar. Hal tersebut juga dapat membuat peserta didik menghindari pelajaran. Pada dasarnya kesulitan belajar matematika bukan dari mereka yang tidak mampu dalam belajar, tetapi kondisi tertentu yang membuat mereka tidak siap dalam belajar.

Terlihat di SD Negerei 155/I Sungai Buluh, guru menggunakan strategi pembelajaran pada berhitung pembagian untuk mengatasi problema yang dialami guru dalam mengajarkan berhitung pembagian. Adapun tujuan dari strategi pembelajaran tersebut diharapkan dapat membantu dalam berhitung pembagian pada peserta didik.

Berdasarkan hasil temuan peneliti yang dikuatkan dengan wawancara dan dokumentasi yang telah dilakukan, berhitung pembagian di kelas II SD Negeri 155/1 Sungai Buluh sudah terlihat dalam proses pembelajaran berhitung pembagian. Hanya saja problema yang guru temui ketika mengajarkan berhitung pembagian, ketika peserta didik sedikit ragu ketika mengerjakan soal pada pembelajaran berhitung pembagian. Didalam berhitung pembagian, peserta didik perlu memahami konsep membagi itu sendiri. Guru mengenalkan konsep membagi pada pserta didik dengan melakukan penjelasan secara berulang-ulang bahwa pembagian tersebut harus dengan mengenal rumusan bagi kali kurang, karena pembagian adalah proses pengurangn secara berulang-ulang. Pada pembelajaran berhitung pembagian sederhana serta mengajarkan konsep sisa pada pembagian tersebut, guru menggunakan metode pembelajaran seperti metode ceramah, metode diskusi, dan metode demonstrasi serta diiringi dengan model pembelajaran yang menarik. Guru juga membantu peserta didik dengan menggunakan media pembelajaran dalam mengenalkan konsep membagi, pembagian sederhana, dan konsep sisa seperti menggunakan media sederhana yang ada disekitar peserta didik. Adapun strategi pembelajaran yang diterapkan oleh guru dalam menghadapi problema ketika mengajarkan berhitung pembagian adalah seperti strategi pembelajaran langsung, dimana pembelajaran guru lebih dominan atau berpusat pada guru dan pembelajaran tidak langsung, dimana peserta didik terlibat didalam proses pembelajaran sehingga adanya interaksi antara guru dan peserta didik.

\section{KESIMPULAN}

Dari hasil penelitian dapat disimpulkan bahwa guru menggunakan strategi pembelajaran untuk mengatasi problema guru dalam mengajarkan berhitung pembagian baik berupa strategi pembelajaran langsung yaitu strategi pembelajaran yang lebih berpusat pada guru, maupun strategi pembelajaran tidak langsung yaitu peserta didik banyak terlibat dalam bentuk tindakan dan guru hanya sebagai fasilitator yang akan membantu proses pembelajaran peserta didik. Dalam mengenalkan konsep membagi, guru menggunakan media pembelajaran sederhana yang dapat membantu dalam proses berhitung pembagian, 
adapun media sederhana yang biasa digunakan oleh guru dalam proses operasi hitung pembagian yaitu seperti lidi, buah-buahan, dan media sederhana lainnya yang ada disekitar lingkungan peserta didik. Media tersebut juga dapat membantu problema yang guru ajarkan, seperti peserta didik yang kurang dalam proses menentukan hasil operasi hitung sendiri . Pembagian sederhana yang dilakukan peserta didik juga diiringi belajar sambil bermain yang diterapkan oleh guru, seperti berhitung sambil menyanyikan yeyel yang sudah dibuat oleh guru. Adapun yang dilakukan guru dalam mengajarakan konsep sisa adalah dengan menggunakan metode ceramah, metode diskusi, serta demonstrasi.

Adapun penelitin yang telah dilakukan peneliti yaitu mendapatkan temuan yang dapat dijadikan sebagai bahan masukan. Guru hendaknya lebih sering menerapkan strategi pembelajaran agar peserta didik dapat termotivasi ketika proses pembelajaran.

\section{DAFTAR PUSTAKA}

Herutman. (2017). Model Pembelajaran Matematika Disekolah Dasar. Bandung: PT Remaja Rosdakarya.

Khairunnisa. (2003). Strategi Pembelajaran Matematika Dengan Menggunakan metode Quantum Learning, Skripsi (Jakarta: Universitas Islam Negeri Syarif Hidayatullah). Majid, Abdul (2013). Strategi Pembelajaran. Bandung: Remaja Rosdakarya Offset. Majid, A. (2014). Strategi Pembelajaran. Jakarta: PT Remaja Rosdakarya.

Priatna, Nanang, dan Ricki Yuliardi. (2018). Pembelajaran Matematika. Bandung: PT Remaja Rosdakarya.

Putra, Wija Sindu. (2015). Analisis kesulitan belajar Matematika Siswa Kelas II Pada Implementasu Kurikulum 2013 Di SD Se-Kecamatan Buleleng. Jurnal PGSD Universitas pendidikan Ganesha, Vol 3 (1), $2015 \mathrm{Hlm} 4$.

Rosmala A, dan Isro'atun. (2018). Model-Model Pembelajaran Matematika. Jakarta: Bumi Aksara.

Rosyadi, Widia. (2016). Analisis Kesulitan Belajar Operasi Hitung Pembagian Pada Siswa Kelas IV SDN Di Kecamatan Winong Kabupaten Pati, Skripsi (Semarang: Universitas Negeri Semarang).

Sari, Luftia Renny. (2018). Peningkatan Ketrampilan Berhitung Mata Pelajaran

Matematika Materi pembagian Bilangan Tiga Angka Menggunakan Media Dakon

Pada Siswa Kelas 3 di SDI Sabilil Falah sukodono, Skripsi (Surabaya: Universitas Islam Negeri

Sunan Ampel Surabaya).

Sugiyono. (2013). Metode Penelitian Kualitatif dan $R \& D$. Bandung: Alfabeta. 
$Y$ antoro, E ndang $P$ utri $S, A$ gung $R$ imba K

P roblema Guru dalam M engajar Kan B erhitung Pembagian di kelas Rendah Sekolah D asar

Sundaya, Rostina. (2016). Media dan Alat Peraga Dalam Pembelajaran Matematika. Bandung : Alfabeta.

Supinah. (2009). Strategi Pembelajaran Matematika SD. Yogyakarta: Departemen Pendidikan Nasional.

Soemarmo, Utari. (2017). Penilaian Pembelajaran Matematika. Bandung: PT Refika Aditama.

Wahyuni, Sri.(2013). Metode Penelitin Kasus. Madura. UTM PRESS. 